\title{
Density, habitat use, and opportunities for conservation of shorebirds in rice fields in southeastern South America
}

\author{
Author(s): Rafael Antunes Dias, Daniel E. Blanco, Andrea P. Goijman, and María Elena Zaccagnini
}

Source: The Condor, 116(3):384-393.

Published By: Cooper Ornithological Society

https://doi.org/10.1650/CONDOR-13-160.1

URL: http://www.bioone.org/doi/full/10.1650/CONDOR-13-160.1

BioOne (www.bioone.org) is a nonprofit, online aggregation of core research in the biological, ecological, and environmental sciences. BioOne provides a sustainable online platform for over 170 journals and books published by nonprofit societies, associations, museums, institutions, and presses.

Your use of this PDF, the BioOne Web site, and all posted and associated content indicates your acceptance of BioOne's Terms of Use, available at www.bioone.org/page/terms_of_use.

Usage of BioOne content is strictly limited to personal, educational, and non-commercial use. Commercial inquiries or rights and permissions requests should be directed to the individual publisher as copyright holder. 


\title{
Density, habitat use, and opportunities for conservation of shorebirds in rice fields in southeastern South America
}

\author{
Rafael Antunes Dias, ${ }^{1, a *}$ Daniel E. Blanco, ${ }^{2}$ Andrea P. Goijman, ${ }^{3, b}$ and María Elena Zaccagnini ${ }^{3}$ \\ 1 Laboratório de Ecologia e Conservação, Universidade Católica de Pelotas, Pelotas, RS, Brazil \\ ${ }^{2}$ Fundación Humedales/Wetlands International, Buenos Aires, Argentina \\ ${ }^{3}$ Grupo Biodiversidad y Gestión Ambiental, Instituto de Recursos Biológicos, INTA-CNIA-Castelar, Buenos Aires, Argentina \\ a Current address: Departamento de Ecologia, Zoologia e Genética, Instituto de Biologia, Universidade Federal de Pelotas, Campus \\ Universitário Capão do Leão, Pelotas, RS, Brazil

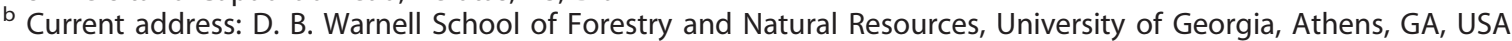 \\ * Corresponding author: rafael.dias@ufpel.edu.br
}

Submitted December 16, 2013; Accepted April 21, 2014; Published July 2, 2014

\begin{abstract}
Worldwide, shorebirds are a major component of rice field avian biodiversity. Rice fields in Argentina and southern Brazil hold large numbers of shorebirds and have been recognized as important areas for migrating or wintering species. To develop successful shorebird conservation strategies, we need to understand geographic variation in shorebird abundance in rice fields as well as how bird use of rice fields varies over the rice growing cycle. We surveyed shorebirds in November and December in the main rice cultivation regions of interior Argentina and coastal Brazil to estimate shorebird densities using distance sampling and to evaluate densities of individual species at different stages of the rice cycle. We detected $>7,000$ shorebirds in rice fields, including a variety of Nearctic migrants. Density of resident species was generally low and showed no differences between countries. Densities of migratory taxa were higher and varied between Brazil and Argentina. Pectoral Sandpiper (Calidris melanotos) and Lesser Yellowlegs (Tringa flavipes) were the most common species in Argentina, but White-rumped Sandpiper (Calidris fuscicollis) and American Golden-Plover (Pluvialis dominica) were the most common species in Brazil. Pectoral Sandpiper density was nearly 8 times higher in Argentina than in Brazil; densities of the White-rumped Sandpiper and American Golden-Plover were 33 and 25 times higher in Brazil than in Argentina. Shorebird density was highest in lightly flooded paddies with rice height $<20 \mathrm{~cm}$. Our findings confirm the importance of rice paddies for shorebirds in southeastern South America and emphasize the need for detailed assessments to ensure that agricultural chemical and water management practices are biodiversity friendly.
\end{abstract}

Keywords: agrobiodiversity, agroecosystem, conservation, agrochemical, distance sampling, irrigated rice, shorebirds

Densidad, uso de hábitat y oportunidades de conservación de aves playeras en campos de arroz del sudeste de América del Sur

\section{RESUMEN}

A nivel global, las aves playeras son uno de los componentes principales de la biodiversidad de avifauna de los campos de arroz. Estos campos en Argentina y el sur de Brasil sustentan grandes números de aves playeras y han sido reconocidos como áreas importantes para especies migratorias o invernantes. Para desarrollar estrategias exitosas de conservación de las aves playeras, necesitamos entender la variación geográfica de la abundancia de las aves playeras en los campos de arroz, así como las variaciones del uso de los campos de arroz a lo largo del ciclo de crecimiento de este cultivo. Con este objetivo, estudiamos las aves playeras en noviembre y diciembre en las principales regiones de cultivo de arroz del interior de Argentina y la costa de Brasil. Estimamos las densidades de aves playeras usando muestreos por distancia y evaluamos las densidades de especies individuales en diferentes etapas del ciclo del arroz. Detectamos $>7000$ aves playeras en los campos de arroz, incluyendo una variedad de migrantes neárticos. La densidad de las especies residentes fue generalmente baja y no mostró diferencias entre países. Las densidades de los taxa migratorios fueron mayores y variaron entre Brasil y Argentina. Calidris melanotos y Tringa flavipes fueron las especies más comunes en Argentina, mientras que Calidris fuscicollis y Pluvialis dominica fueron las especies más comunes en Brasil. La densidad de C. melanotos fue casi ocho veces mayor en Argentina que en Brasil; las densidades de $C$. fuscicollis y $P$. dominica fueron 33 y 25 veces mayores en Brasil que en Argentina. La densidad de aves playeras fue mayor en los arrozales someramente inundados con alturas de arroz $<20 \mathrm{~cm}$. Nuestros resultados confirman la importancia de los arrozales para las aves playeras en el sudeste de América del Sur y enfatizan la necesidad de 
evaluaciones detalladas para asegurar que las prácticas de manejo de los agroquímicos y del agua son amigables con la biodiversidad.

Palabras clave: agrobiodiversidad, agroecosistemas, agroquímicos, arroz irrigado, aves playeras, conservación, muestro por distancia

\section{INTRODUCTION}

A substantial portion of arable land worldwide is dedicated to rice (Oryza sativa) cultivation. Occupying more than $156 \times 10^{3}$ ha annually, this crop is a primary source of nutrition for more than half the world's human population and constitutes more than one-fifth of the global grain supply (Elphick 2010). Irrigated rice is probably the most biodiversity friendly crop, harboring rich communities of aquatic plants and animals (Bambaradeniya et al. 2004, Leitão et al. 2007, Elphick 2010, Rolon and Maltchik 2010). While expansion of rice fields is a major cause of natural wetland destruction (Blanco et al. 2006, Cho 2007), rice paddies are often the only aquatic habitat left in some regions, which raises their conservation value (see Elphick 2010 and references therein).

Birds are a main component of rice field biodiversity, both in species richness and abundance. The most common groups of species using paddies are typical of shallow wetlands, especially waterfowl (geese, swans, and ducks), long-legged wading birds (herons, egrets, bitterns, ibises, and storks), shorebirds (plovers, sandpipers, gulls, and terns), and gruiforms (cranes, rails, crakes, coots, and gallinules; Elphick 2010). Birds seek rice fields mostly for foraging and, to a lesser extent, for roosting and breeding (Fasola and Ruiz 1996, Elphick 2010).

Use of paddies by birds is mediated by the ricegrowing cycle (Elphick 2010). The length of the irrigation period, water depth, agrochemical use, rice height and density, rice-cycle duration, and human disturbance are important factors determining the diversity of birds in rice fields (Dias and Burger 2005). Shorebirds are especially numerous at the onset of the growing period when they forage in lightly flooded paddies with short and sparse rice plants, but they can also be abundant in fallow and harvested fields (Elphick and Oring 2003, Blanco et al. 2006, Acosta et al. 2010, Taylor and Schultz 2010). In southeastern South America, at least 18 species of birds in the Charadriidae, Recurvirostridae, Scolopacidae, Jacanidae, and Rostratulidae families occur in rice fields, including 12 species of long-distance migrants from North America (Blanco et al. 2006, Acosta et al. 2010).

Rice fields in Argentina and southern Brazil hold large numbers of shorebirds and have been recognized as important areas for migrating or wintering species (Figure 1; Blanco et al. 2006); however, density estimates considering detectability functions for shorebirds in these areas are still lacking. Further, little is known about how densities vary in relation to stages of the rice growing cycle, information needed to ascertain the conservation value of the rice crop to shorebirds and to guide the establishment of biodiversity friendly management practices (Elphick et al. 2010). Information on when and how shorebirds use rice fields is also needed to assess potential exposure of shorebirds to fungicides, herbicides, and insecticides used to control pests (Blanco et al. 2006). Exposure information is especially relevant because lethal and sublethal effects of agrochemicals have been recorded in shorebirds (Parsons et al. 2010, Strum et al. 2010), and paddies might be acting as toxic traps if they attract birds away from alternative foraging habitats.

The primary objective of this study was to estimate the density of resident and Nearctic migratory shorebirds in rice fields in southeastern South America. We also evaluated how density varies in relation to the different phases of the rice-growing cycle.

\section{METHODS}

\section{Study Area}

We sampled shorebirds in the main irrigated rice cultivation regions of Argentina and Brazil (Figure 2) during the austral spring (November and December) of 2004. Information on agricultural practices (summarized below) follow Dias and Burger (2005) and Blanco et al. (2006). In both countries, we sampled rice paddies grown under the "conventional" system, which demands use of heavy machinery and agrochemical input. Farms in the region vary from 150 to $>20,000$ ha and alternate rice growing with livestock ranching on the same plots of land. Soil preparation usually occurs 3 months to several weeks before sowing. In both countries, the chemical glyphosate is sprayed on the bare soil before sowing. Rice seeds are drilled into the soil, and flooding starts 30-45 days after the plants emerge. Water for irrigation is diverted from natural wetlands or manmade reservoirs. Water level is maintained at 5-15 cm during the initial phases of the rice cycle, which lasts some 5 weeks, and then raised to 15-25 $\mathrm{cm}$ during the reproductive stage. In total, rice fields are flooded 90-100 days. Paddies are drained after the grain has reached physiological maturity. Spraying of postemergence herbicides normally takes place immediately before paddies are flooded. Fungicides are used at the onset of the flowering phase; insecticides are usually sprayed before flooding, but applications of specific 


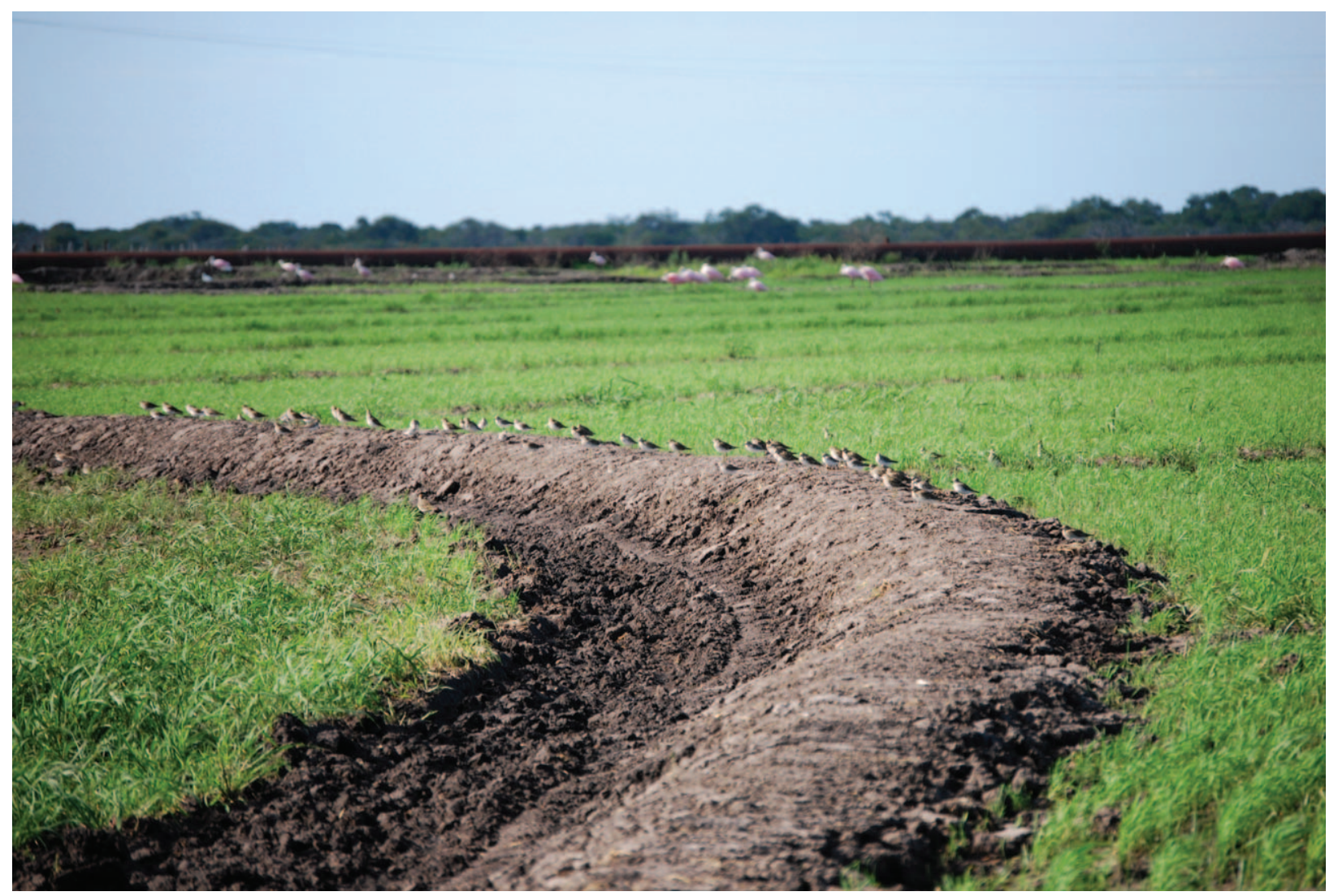

FIGURE 1. Shorebirds, mainly Pectoral Sandpipers (Calidris melanotos), resting on a levee in a rice field at Estancia La Lucha, Argentina, January 2010. Photo credit: Arne Lesterhuis

products can occur as late as the grain maturation phase depending on pest infestations.

In Argentina we sampled rice fields near the city of San Javier $\left(30^{\circ} 35^{\prime} \mathrm{S}, 59^{\circ} 57^{\prime} \mathrm{W}\right)$, Santa Fe province. Rice is cultivated in the floodplains of the Paraná River, occupying a north-south band $\sim 15-20 \mathrm{~km}$ wide and $100 \mathrm{~km}$ long (Alvisio 1998, Ruiz 1998). Rice is sown annually between September and late November and is harvested in March (Ruiz 1998). Rice fields in the region covered 16,660 ha in the 2004-2005 season (M. Serra personal communication).

In Brazil we sampled rice fields in southern Rio Grande do Sul state, in the municipalities of Rio Grande $\left(32^{\circ} 02^{\prime} \mathrm{S}\right.$, $\left.52^{\circ} 05^{\prime} \mathrm{W}\right)$, Jaguarão $\left(32^{\circ} 34^{\prime} \mathrm{S}, 52^{\circ} 23^{\prime} \mathrm{W}\right)$, and Santa Vitória do Palmar $\left(33^{\circ} 31^{\prime} \mathrm{S}, 53^{\circ} 21^{\prime} \mathrm{W}\right)$, a region located in the Mirim lagoon and São Gonçalo channel catchment areas. Rice is grown in floodplains along lagoons and in comparatively higher sedimentary terrains of the coastal plain. Sowing takes place between October and December, with harvest in late February through May (IRGA 2001, Dias and Burger 2005). In the 2004-2005 season, 107,596 ha of rice were cultivated in Rio Grande, Jaguarão, and Santa Vitória do Palmar municipalities (ITEPA 2011).

\section{Bird Surveys}

Surveys were carried out in November and December, when most rice fields are in the vegetative phase of the rice cultivation cycle (IRGA 2001). During this initial stage, paddies are lightly flooded, rice cover is sparse, and shorebirds are numerous (Dias and Burger 2005, Blanco et al. 2006). Surveys were conducted by vehicle along small access roads and paths amid rice paddies.

We nonrandomly selected localities for sampling based on the presence of rice fields under cultivation. When a rice field was located, we sampled the first paddy we could access by road and systematically sampled the others along the road or path until the limit of the farm was reached. We then searched for another access road or path and repeated the process until the whole farm was sampled.

We counted birds using a 150-m fixed-radius circular or semicircular plot because our previous experience with shorebirds in local grassland and rice field habitats indicated that birds are seldom detected when distances exceed $200 \mathrm{~m}$ (Lanctot et al. 2002; D. E. Blanco and R. A. Dias personal observation). Semicircular plots were used when roads sectioning paddies were wide or, in a few cases, when rice fields occupied only one side of the road. When roads sectioned the paddies, we clustered bird and habitat 


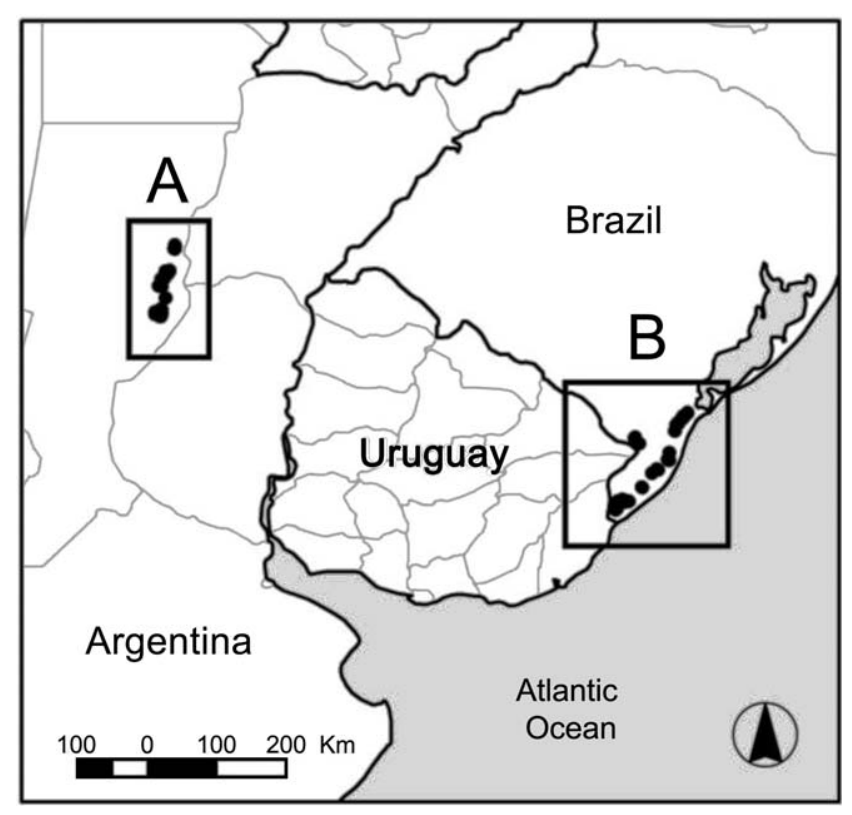

FIGURE 2. Study area in southeastern South America, with localities sampled in Argentina (A) and in the coastal plain of southern Brazil (B).

data from both semicircles and treated the sample as a single circular plot for analyses. A minimum distance of $500 \mathrm{~m}$ was maintained between plots to ensure they were independent of one another. The number of plots per farm varied from 2 to 19. Our final sample consisted of 106 plots in 14 farms in Argentina and 77 plots in 15 farms in Brazil.

Counts were conducted from the center of the plot by 1 or 2 observers using binoculars and spotting scopes. All shorebirds detected within the plot for a period of $10 \mathrm{~min}$ were counted. We recorded shorebird species, number of individuals, radial distance to the observer, and behavior for each bird or group of birds. A cluster can be defined as a relatively tight aggregation of objects of interest, as opposed to a loosely clumped spatial distribution of objects (Buckland et al. 2001). We considered a group or cluster as an aggregation (i.e. a pair or a flock) of the birds of interest in this study. Distances from the observer were estimated to the nearest $10 \mathrm{~m}$. We used handheld GPS to determine geographical coordinates for each plot and to measure distances between them.

We attributed each plot to a growing stage based on the height and density of the rice plants and flooding conditions of the paddy: Stage 1-rice recently germinated, sparse vegetation cover, paddy not flooded; Stage 2-rice plants $<20 \mathrm{~cm}$ high, sparse vegetation cover, paddy lightly flooded (water depth $<15 \mathrm{~cm}$ ); Stage 3-rice plants $>20$ $\mathrm{cm}$ high, ample vegetation cover, paddy fully flooded (water depth $>15 \mathrm{~cm}$ ). Fallow fields were not sampled.

\section{Data Analyses}

For each species, we calculated the percentage of plots in which it was recorded. We used program DISTANCE (version 5.0; Thomas et al. 2006) to estimate densities for shorebirds. DISTANCE estimates density by fitting to a set of models the probability of detecting a given species as a function of its perpendicular distance from the observer. Densities were estimated from grouped data and considering clusters of birds. Our goal was to model densities for species with $>80$ observation records in both countries, which is the minimum number of objects recommended to estimate densities of objects using this approach (Buckland et al. 2001). Due to the low number of observations of some of these species in a country or rice stage category, however, we occasionally modeled densities with $<80$ observation records (see Results).

Shorebirds were rarely detected near the observation point because the center of plots was usually on roads and trails bordering or crossing paddies. To eliminate bias in density estimates due to birds moving away from observers, we left truncated distances (Buckland et al. 2001), excluding records between 0-10 m after exploring the shape of the observation curve for each species.

First, we estimated shorebird densities for Argentina and Brazil separately. The detection probability function was explored both globally and post-stratified by rice stage (Buckland et al. 2001). Manual selection of distance intervals for each species was initially explored, as recommended by Buckland et al. (2001), with cut points based on the distribution of observations at different distances, looking for the best fit of the detection curves. Once the distance classes were selected for each species, we selected the best models and adjustment terms (discussed later) based on Akaike's Information Criterion (AIC; Buckland et al. 2001). Second, we estimated shorebird densities prestratified by the 3 rice stages. Because we were interested in densities per rice stage, observations from both countries were grouped to increase the number of records per rice stage category, which increases the reliability of density estimates. We followed the same steps described above to explore the distance intervals, following the selection of the best models to estimate density per strata.

Densities of American Golden-Plover (Pluvialis dominica), White-rumped Sandpiper (Calidris fuscicollis), and Buff-breasted Sandpiper (Calidris subruficollis) were estimated only for Brazil due to insufficient records in Argentina. Because of the scarcity of observations per rice stage category for Buff-breasted Sandpiper and Blacknecked Stilt (Himantopus mexicanus melanurus), we considered the global detection function post-stratified by rice stage. In this case, the density is the average of the estimates by stratum, weighted by the effort in each stratum (Thomas et al. 2006). 
TABLE 1. Abundance (total individuals counted) and incidence (percentage of plots occupied) of resident (R) and Nearctic migratory (M) shorebirds in rice fields of Argentina (Ar) and Brazil (Br). The number of plots $(n)$ sampled in each country is listed below the acronym. NR - not recorded; O - observed in rice paddies, but outside sampling plots; IC - recorded only in irrigation channels.

\begin{tabular}{|c|c|c|c|c|c|c|}
\hline Family/Species & Scientific name & Status & $\operatorname{Ar}(n=106)$ & $\mathrm{Br}(n=77)$ & \multicolumn{2}{|c|}{ Combined } \\
\hline \multicolumn{7}{|l|}{ Recurvirostridae } \\
\hline Black-necked Stilt & Himantopus mexicanus melanurus & $\mathrm{R}$ & $143(13 \%)$ & $161(19 \%)$ & 304 & $16 \%$ \\
\hline \multicolumn{7}{|l|}{ Charadriidae } \\
\hline Southern Lapwing & Vanellus chilensis & $\mathrm{R}$ & 406 (78\%) & $1,049(99 \%)$ & 1,455 & $88.5 \%$ \\
\hline American Golden-Plover & Pluvialis dominica & M & 55 (13\%) & $1,914(32 \%)$ & 1,969 & $22.5 \%$ \\
\hline Collared Plover & Charadrius collaris & $\mathrm{R}$ & $26(9 \%)$ & $\mathrm{O}$ & 26 & $4.5 \%$ \\
\hline \multicolumn{7}{|l|}{ Jacanidae } \\
\hline Wattled Jacana & Jacana jacana & $\mathrm{R}$ & $6(1 \%)$ & IC & 6 & $0.5 \%$ \\
\hline \multicolumn{7}{|l|}{ Scolopacidae } \\
\hline South American Snipe & Gallinago paraguaiae & $\mathrm{R}$ & $45(17 \%)$ & $1(1 \%)$ & 46 & $9 \%$ \\
\hline Hudsonian Godwit & Limosa haemastica & M & $1(1 \%)$ & $4(1 \%)$ & 5 & $1 \%$ \\
\hline Upland Sandpiper & Bartramia longicauda & M & $12(3 \%)$ & NR & 12 & $1.5 \%$ \\
\hline Greater Yellowlegs & Tringa melanoleuca & M & $10(4 \%)$ & $23(16 \%)$ & 33 & $10 \%$ \\
\hline Lesser Yellowlegs & Tringa flavipes & M & 308 (40\%) & $442(32 \%)$ & 750 & $36 \%$ \\
\hline Solitary Sandpiper & Tringa solitaria & M & $4(4 \%)$ & NR & 4 & $2 \%$ \\
\hline White-rumped Sandpiper & Calidris fuscicollis & M & $9(16 \%)$ & $1,181(23 \%)$ & 1,190 & $19.5 \%$ \\
\hline Pectoral Sandpiper & Calidris melanotos & M & $1,133(71 \%)$ & $77(22 \%)$ & 1,210 & $46.5 \%$ \\
\hline Stilt Sandpiper & Calidris himantopus & M & NR & $19(5 \%)$ & 19 & $2.5 \%$ \\
\hline Buff-breasted Sandpiper & Calidris subruficollis & M & NR & $107(12 \%)$ & 107 & $6 \%$ \\
\hline Wilson's Phalarope & Phalaropus tricolor & M & $\mathrm{O}$ & $9(5 \%)$ & 9 & $2.5 \%$ \\
\hline Total species & & & 13 & 12 & & \\
\hline Total abundance & & & 2,158 & 4,987 & 7,145 & \\
\hline
\end{tabular}

We used the uniform model (with the series expansion cosine and simple polynomial) and half normal (with series expansion cosine and hermite polynomial) to analyze the detection function for each species separately, assuming the detection function follows a parametric form (Buckland et al. 2001). We selected these models with the correspondent series expansions based on the shape of the detection function, which decreased with distance from the center of the point, and because they are the most parsimonious models (i.e. compared to hazard-rate models that require a priori assumptions about the detection process). Densities (birds $\mathrm{ha}^{-1}$ ) were estimated by the selection of the model with the best adjustment based on chi-square $\left(\chi^{2}\right)$ goodness-of-fit tests. Additionally, a visual analysis of the detection probability and probability density plots was conducted. The most parsimonious models for each set were selected based on the minimization of the AIC (Buckland et al. 2001). We present density estimates \pm SE and $90 \%$ confidence intervals (CI 90\%). Estimates with nonoverlapping intervals were considered different.

\section{RESULTS}

\section{Shorebird Abundance, Incidence, and Density}

We recorded 7,145 individuals of 16 species of shorebirds in rice fields, including 11 Nearctic migrants and 5 Neotropical resident species (Table 1). The Southern
Lapwing (Vanellus chilensis) had the highest incidence values in both Argentina and Brazil.

We estimated densities for 7 species (Figure 3). In Argentina, Pectoral Sandpiper (Calidris melanotos) was $\sim 3$ times as common as the next most common species, Lesser Yellowlegs (Tringa flavipes). In Brazil, densities of these 2 species were reduced by $\sim 75 \%$, and White-rumped Sandpiper and American Golden-Plover were the most common species, which were $\sim 30$ times more common in Brazil than in Argentina but with wider confidence intervals. Buff-breasted Sandpiper was only recorded in Brazil. Southern Lapwing and Black-necked Stilt displayed similar densities in both countries.

\section{Densities per Rice Stage}

Shorebird densities varied between rice stage categories (Table 2). All species displayed lower densities in Stage 1 than in Stage 2. Densities of the Pectoral Sandpiper, Blacknecked Stilt, and Lesser Yellowlegs were especially low in dry paddies with recently germinated rice (Stage 1). Densities of all species tended to reach maximum values at Stage 2, when paddies are flooded and rice plants are shorter than $20 \mathrm{~cm}$ (Table 2). Lesser Yellowlegs, Pectoral Sandpiper, Black-necked Stilt, and Southern Lapwing also displayed high densities in flooded paddies with rice plants $>20 \mathrm{~cm}$ high (Stage 3). The other species tended to display lower densities or were absent during this stage. 


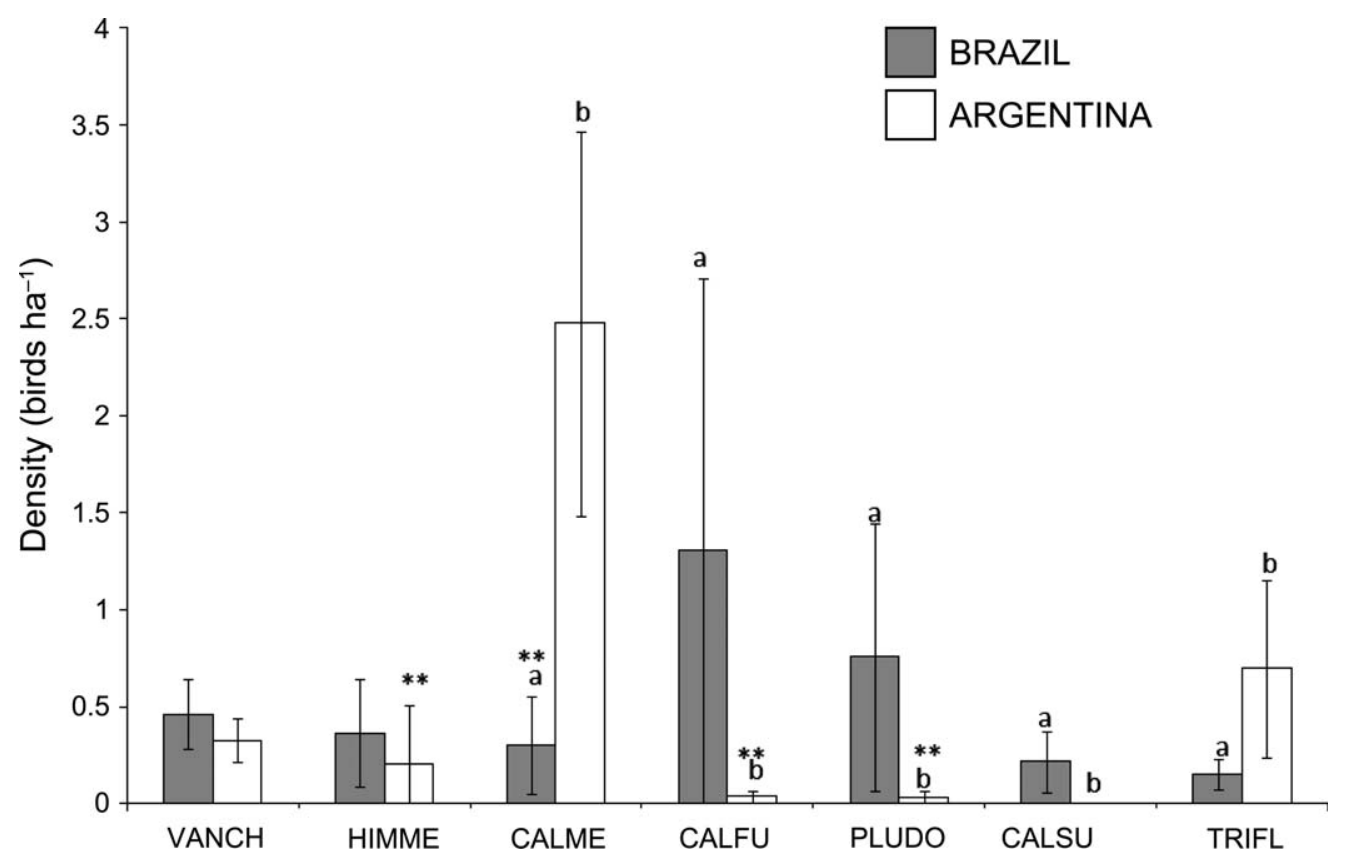

FIGURE 3. Estimated densities of Southern Lapwing (VANCH), Black-necked Stilt (HIMME), Pectoral Sandpiper (CALME), Whiterumped Sandpiper (CALFU), American Golden-Plover (PLUDO), Buff-breasted Sandpiper (CALSU), and Lesser Yellowlegs (TRIFL) in rice fields in Argentina and Brazil. Bars indicate $90 \%$ confidence intervals $(\mathrm{Cl})$. Different letters $(\mathrm{a}, \mathrm{b})$ indicate nonoverlapping $90 \% \mathrm{Cl}$ for the same species between countries; ${ }^{* *}$ indicates densities estimated with $<80$ observations.

\section{DISCUSSION}

Our results demonstrate that shorebirds attain high densities in rice fields in northeastern Argentina and southern Brazil during the austral spring. We detected differences in densities of migratory species between countries. Densities also varied in relation to the structure of the habitat in paddies. Most species were more numerous in lightly flooded paddies with short rice plants. Only larger, longer legged, or more aquatic species were able to make use of flooded and densely vegetated rice fields. Because large numbers of shorebirds use rice fields throughout our study area, negative impacts of rice cultivation practices are likely to affect these species.
The most abundant and frequent shorebirds in rice fields throughout our study area inhabit lightly flooded freshwater habitats in the Neotropics (Black-necked Stilt, Lesser Yellowlegs, Pectoral Sandpiper, and White-rumped Sandpipers) or short-grass grasslands (Southern Lapwing, American Golden-Plover, and Buff-breasted Sandpiper; del Hoyo et al. 1996, Blanco et al. 2006). Rare species in our sample use other types of habitat in the region, such as oceanic beaches or mud and sand flats in estuaries, or do not have their primary wintering quarters in our study area. Species that migrate south along the Western Amazonia, Central Amazonia, and Central Brazil flyways (Antas 1983) tended to be more common throughout our study area than those using Andean and Atlantic flyways,

TABLE 2. Shorebird densities (birds ha ${ }^{-1}$ ) \pm standard errors (SE) by rice cycle stage. Stage 1: rice recently germinated, sparse vegetation cover, paddy not flooded; Stage 2: rice plants $<20 \mathrm{~cm}$ high, sparse vegetation cover, paddy lightly flooded; Stage 3: rice plants $>20 \mathrm{~cm}$ high, ample vegetation cover, paddy fully flooded. Different superscripted letters (a, b, and c) indicate nonoverlapping $90 \% \mathrm{Cl}$ between stages; * indicates estimation using a global detection function; ${ }^{*}$ indicates densities estimated with $<80$ observations.

\begin{tabular}{llccc}
\hline Species & Country & Stage $1(n=35)$ & Stage $2(n=81)$ & Stage 3 $(n=65)$ \\
\hline Black-necked Stilt & $\mathrm{Ar}+\mathrm{Br}$ & $0.01(0.01)^{*}$ & $0.61(0.35)^{*}$ & $0.28(0.12)^{*}$ \\
Southern Lapwing & $\mathrm{Ar}+\mathrm{Br}$ & $0.10(0.03)^{\mathrm{a}}$ & $0.80(0.16)^{\mathrm{b}}$ & $0.38(0.07)^{\mathrm{c}}$ \\
American Golden-Plover & $\mathrm{Br}$ & $0.18(0.17)$ & $1.37(0.81)$ & $0.03(0.01)^{* *}$ \\
Lesser Yellowlegs & $\mathrm{Ar}+\mathrm{Br}$ & $0.04(0.03)^{* * a}$ & $0.54(0.23)^{\mathrm{b}}$ & $0.52(0.28)^{\mathrm{b}}$ \\
White-rumped Sandpiper & $\mathrm{Br}$ & $0.52(0.89)^{* *}$ & $3.87(4.35)$ & $0.06(0.06)^{* *}$ \\
Pectoral Sandpiper & $\mathrm{Ar}+\mathrm{Br}$ & $0.02(0.02)^{* * a}$ & $2.92(1.04)^{\mathrm{b}}$ & $1.54(0.65)^{\mathrm{b}}$ \\
Buff-breasted Sandpiper & $\mathrm{Br}$ & $0.11(0.11)^{*}$ & $0.32(0.15)^{*}$ & - \\
\hline
\end{tabular}


such as the Stilt Sandpiper (Calidris himantopus) and Wilson's Phalarope (Phalaropus tricolor).

Density of resident species (Black-necked Stilt and Southern Lapwing) was similar in Argentina and Brazil, reflecting their widespread distribution in southeastern South America (del Hoyo et al. 1996). In contrast, densities of Nearctic migrants varied between countries, possibly reflecting specific differences in migration routes and the location of the main nonbreeding range in South America. Shorebirds whose main wintering range is located along the coast, namely the American Golden-Plover, White-rumped Sandpiper, and Buff-breasted Sandpiper (Lanctot et al. 2002, Blanco et al. 2008a, 2008b), displayed higher densities in Brazil than in Argentina. The Pectoral Sandpiper and Lesser Yellowlegs, which are more numerous in inland wetlands along the Paraná River (Blanco et al. 2008c, 2008d), displayed higher densities in Argentinean paddies.

Shorebird densities also varied in relation to habitat structure, a finding consistent with previous studies (Martínez-Vilalta 1985, Riera et al. 1997-1998, Dias and Burger 2005, Blanco et al. 2006). The majority of species showed preference for lightly flooded paddies with rice $<20 \mathrm{~cm}$ high. Larger, longer legged, or more aquatic species, such as the Southern Lapwing, Lesser Yellowlegs, and the Pectoral Sandpiper, were also more abundant in flooded and densely vegetated paddies. The Southern Lapwing, American Golden-Plover, and Buff-breasted Sandpiper, which displayed the highest densities in dry rice fields, are grassland birds adapted to forage in drier situations. The White-rumped Sandpiper, a predominantly wetland species, was unexpectedly numerous in dry rice fields in Brazil; however, the high density of this bird in such conditions is explained by the presence of muddy depressions in some dry paddies in the process of being flooded, where large numbers of sandpipers concentrated.

Densities of most species declined as rice plants developed. Marked decreases in shorebird abundance during the final stages of the tillering phase of rice have been previously described (Fasola and Ruiz 1996, Mugica et al. 2003, Dias and Burger 2005, Blanco et al. 2006) and observed also for phytoplankton, rotifers, filter-feeding cladocerans, Oligochaeta, and Chironomidae (Forés and Comín 1992, Leitão et al. 2007). Alterations in physical and chemical characteristics of the water that result from shading by developing rice plants are the main explanation for such shifts (Forés and Comín 1992, Leitão et al. 2007). Shorebirds in our study area use rice fields mainly for foraging (Dias and Burger 2005, Blanco et al. 2006); therefore, in addition to changes in the composition of prey assemblages, shorebirds might also be affected by difficulties in finding and capturing invertebrate prey in deeper water and denser vegetation (Dias and Burger 2005), or because predator detection may be higher in open vistas (C. Elphick personal communication).
Although a series of studies report densities of shorebirds in rice fields in other localities (Hicklin and Spaans 1992, Lourenço and Piersma 2009, Ibáñez et al. 2010, Taylor and Schultz 2010, Norling et al. 2012), direct comparisons are hampered by differences in sampling methods, rice cultivation practices, and how detectability was incorporated in the analyses. Nonetheless, our density estimates for Black-necked Stilt are in the range of mean estimates for Himantopus stilts in active rice paddies in Europe and Australia, which varied from 0.06 to 0.99 individuals ha $^{-1}$ (Ibáñez et al. 2010, Taylor and Schultz 2010).

Our estimates for the American Golden-Plover are also similar to mean densities reported for active rice fields in Surinam, where $0.1-0.3$ individuals $\mathrm{ha}^{-1}$ were estimated according to the stage of rice cultivation (Hicklin and Spaans 1992). Mean densities of the Lesser Yellowlegs in Surinam varied from 0.1 to 7.8 individuals ha ${ }^{-1}$ (Hicklin and Spaans 1992), with upper values considerably larger than our estimates. One of the highest abundances of this species in South America is found along the northern Atlantic coast (Blanco et al. 2008d), which might account for these differences. Densities of White-rumped Sandpipers in Surinam varied from 0.1 to 0.7 individuals ha $^{-1}$ (Hicklin and Spaans 1992), lower than our estimates for southeastern South America.

Comparisons of shorebird densities in rice fields and natural areas are crucial to assess the relative importance of rice fields in the region; however, the only work that estimated densities of shorebirds in natural habitats in our study area using comparable methods focused on the Buffbreasted Sandpiper (Lanctot et al. 2002). Although year-toyear variations may occur, the estimated density of 1.62 individuals $\mathrm{ha}^{-1}(95 \%$ C.I. $=0.67-3.93)$ on grasslands of southern Brazil (Lanctot et al. 2002) suggests that the species is more numerous in natural habitat than in rice fields. Density estimates using distance methods are also available for some shorebirds in inland Uruguayan grasslands where rice is not cultivated (Azpiroz and Blake 2009). Mean densities of the Southern Lapwing in this region varied from 0.28 to 0.49 individuals $\mathrm{ha}^{-1}$ (Azpiroz and Blake 2009). These values are somewhat similar to our estimates, with the exception of lightly flooded paddies, where lapwing densities were much higher. Densities of the American Golden-Plover in inland Uruguay were much lower than in rice fields, varying from 0.01 to 0.05 individuals $\mathrm{ha}^{-1}$ (Azpiroz and Blake 2009); however, this species is more abundant along the coast, so differences might reflect their distribution.

Our results raise an obvious question: What is the total number of migratory and resident shorebirds using rice fields in Argentina and southern Brazil? Using the proportion of each rice stage occurring within our sampling plots to estimate the total area covered per stage 
in each country and extrapolating our mean density estimates for each rice stage would result in $\sim 682,500$ shorebirds using rice fields in our study area $(\sim 53,500$ in Argentina and $\sim 629,000$ in Brazil). Among migratory species, $\sim 234,000$ Pectoral Sandpipers, 195,500 Whiterumped Sandpipers, 69,500 American Golden-Plovers, 55,000 Lesser Yellowlegs, and 19,000 Buff-breasted Sandpipers would occur in rice fields in our study area.

These figures must be treated with caution due to sampling biases and extrapolation problems. First, our density estimates frequently have large confidence intervals, which occasionally overlap with zero (Lanctot et al. 2008). Such variability probably reflects the difficulty in recognizing independent clusters in shorebirds due to their gregarious nature or problems with the underlying estimation model. Second, we did not randomly select rice paddies; thus, we cannot be sure that extrapolations of our density estimates can be meaningful, even though they may still lie close to true density (Thompson 2002, Bächler and Liechti 2007). Third, even with unbiased estimates, the time required to conduct our surveys, the high mobility of shorebirds in rice fields (Hicklin and Spaans 1992), the dynamic nature of the rice crop, and the variation of bird densities as rice plants develop, would still hinder extrapolations (A. Farmer personal communication).

Despite all these limitations, we can safely assume that hundreds of thousands of shorebirds use rice fields during the austral spring in our study area. Estimates from other parts of the world also indicate that large numbers of shorebirds use rice fields. In coastal Surinam, nearly 8,000 shorebirds were counted in rice fields in a 10,000 ha plantation in 1989 (Hicklin and Spaans 1992). About 1.4 to $>1.6$ million shorebirds used rice field habitats in the southern United States in 1997 and 1998, respectively (Norling et al. 2012).

If our estimates are realistic, rice fields in southeastern South America hold high concentrations of shorebirds and may harbor an important proportion of the global population of some species. Thus, the rice growing regions along the Paraná River in Santa Fé in Argentina and the Lagoa Mirim in southern Brazil could be considered landscapes of Hemispheric Importance of the Western Hemisphere Shorebird Reserve Network (WHSRN), similar to the Sacramento Valley in California (WHSRN 2014). The rice growing area of San Javier has already been listed as an Important Bird Area because of its outstanding concentrations of Bobolinks (Dolichonyx oryzivorus) and the presence of Buff-breasted Sandpipers (López-Lanús and Blanco 2005). To fully satisfy WHSRN criteria, additional efforts must be made to verify these concentrations and their predictability.

One of the challenges in conserving biodiversity in agroecosystems is integrating agricultural and conserva- tion practices without affecting the economic viability of the crop (Scherr and McNeely 2008). The large numbers of shorebirds recorded in rice fields suggest that local management practices (especially the irrigation regime of paddies) and growth characteristics of cultivars produce suitable foraging habitat for these species. If further studies demonstrate that paddies are not toxic traps and that irrigation is not detrimental to the water balance of adjacent natural wetlands, current agronomical practices used in conventional rice fields in southeastern South America may turn out to be "biodiversity friendly," and local rice lands could constitute genuine "ecoagricultural" landscapes (Scherr and McNeely 2008). Most important, there would be no need for major changes in management practices that could jeopardize the profitability of the crop. These assessments alongside our results could raise the conservation value of conventional rice in South America, a most desirable strategy considering the large acreage and broad market niche of this crop (Elphick et al. 2010).

We demonstrated that rice paddies in southeastern South America are used by substantial numbers of shorebirds. Current rice cultivation practices likely provide suitable habitat for these birds. To fully understand the conservation value of this crop, however, a detailed assessment is still needed to evaluate if rice fields are used as additional foraging habitat as opposed to replacement habitat and to ensure that agricultural practices related with agrochemical and water use are biodiversity friendly. At least one species using paddies in our study area, the Buff-Breasted Sandpiper, may already be impacted by contaminants in rice fields (Strum et al. 2010). Such measures are especially important because migratory species are a major component of the shorebird assemblage, and management practices affecting this conservation-concern species group are expected to reflect across the Americas.

\section{ACKNOWLEDGMENTS}

We thank colleagues A. Azpiroz and F. Rilla Manta and field assistants J. Aldabe, C. B. Andretti, M. P. Cirne, M. S. S. Gonçalves, P. Petracci, H. Ramírez, P. Rocca, and I. Roesler. M. Serra and G. Perusini provided information and local support for fieldwork in San Javier. A series of landowners and their teams assisted with logistics in the field and crop information. We are also indebted to J. Bernardos and S. Canavelli for advice with data analyses. V. A. G. Bastazini, C. Ephick, and R. Lanctot provided useful thoughts and comments that improved the manuscript. This project was funded by the Neotropical Migratory Bird Conservation Act, Division of Bird Habitat Conservation, U.S. Fish \& Wildlife Service (USF\&WS). Institutional support was provided by Wetlands International, Universidade Católica de Pelotas, and Instituto Nacional de Tecnología Agropecuaria. 


\section{LITERATURE CITED}

Acosta, M., L. Mugica, D. E. Blanco, B. López-Lanús, R. A. Dias, L. W. Doodnath, and J. Hurtado (2010). Birds of rice fields in the Americas. Waterbirds 33:105-122.

Alvisio, A. (1998). Arroz. Modelos zonales de producción en el movimiento CREA: Región Litoral Norte. Cuadernillo de Actualización Técnica 61:141-145.

Antas, P. T. Z. (1983). Migration of nearctic shorebirds (Charadriidae and Scolopacidae) in Brazil-Flyways and their different seasonal use. Wader Study Group Bulletin 39:52-56.

Azpiroz, A., and J. G. Blake (2009). Avian assemblages in altered and natural grasslands in the Northern Campos of Uruguay. The Condor 111:21-35.

Bächler, E., and F. Liechti (2007). On the importance of $g(0)$ for estimating bird population densities with standard distancesampling: Implications from a telemetry study and a literature review. Ibis 149:693-700.

Bambaradeniya, C. N. B, J. P. Edirisinghe, D. N. Silva, C. V. S. Gunatilleke, K. B. Ranawana, and S. Wijekoon (2004). Biodiversity associated with an irrigated rice agroecosystem in Sri Lanka. Biodiversity and Conservation 13:1715-1753.

Blanco D. E., R. Baigún, and B. López-Lanús (2008a). American Golden-Plover in South America factsheet. http://lac.wetlands. org/Loquehacemos/WetlandBiodiversityandWaterbirds/ Mapasdeavesacu\%C3\%A1ticas/AmericanGoldenPlover/tabid/ 2169/Default.aspx

Blanco D. E., R. Baigún, and B. López-Lanús (2008b). White-rumped Sandpiper in South America factsheet. http://lac.wetlands.org/ Loquehacemos/WetlandBiodiversityandWaterbirds/ Mapasdeavesacu\%C3\%A1ticas/WhiterumpedSandpiper/tabid/ 2195/Default.aspx

Blanco D. E., R. Baigún, and B. López-Lanús (2008c). Pectoral Sandpiper in South America factsheet. http://lac.wetlands. org/Loquehacemos/WetlandBiodiversityandWaterbirds/ Mapasdeavesacu\%C3\%A1ticas/PectoralSandpiper/tabid/ 2180/Default.aspx

Blanco D. E., R. Baigún, and B. López-Lanús (2008d). Lesser Yellowlegs in South America factsheet. http://lac.wetlands. org/Loquehacemos/WetlandBiodiversityandWaterbirds/ Mapasdeavesacu\%C3\%A1ticas/LesserYellowlegs/tabid/2178/ Default.aspx

Blanco, D. E., B. López-Lanús, R. A. Dias, A. Azpiroz, and F. Rilla (2006). Uso de arroceras por chorlos y playeros migratorios en el sur de América del Sur. Implicancias de conservación y manejo. Wetlands International, Buenos Aires, Argentina.

Buckland, S. T., D. R. Anderson, K. P. Burham, J. L. Laake, D. L. Borchers, and L. Thomas (2001). Introduction to Distance Sampling. Estimating Abundance of Biological Populations. Oxford University Press, New York, USA.

Cho, D. O. (2007). The evolution and resolution of conflicts on Saemangeum Reclamation Project. Ocean and Coastal Management 50:930-944.

del Hoyo, J., A. Elliott, and J. Sargatal (Editors) (1996). Handbook of the birds of the world, volume 3. Hoatzin to Auks. Lynx Edicions, Barcelona, Spain.

Dias, R. A., and M. I. Burger (2005). A assembléia de aves de áreas úmidas em dois sistemas de cultivo de arroz irrigado no extremo sul do Brasil. Ararajuba 13:63-80.
Elphick, C. S. 2010. Why study birds in rice fields? Waterbirds 33: $1-7$.

Elphick, C. S., P. Baicich, K. C. Parsons, M. Fasola, and L. Mugica (2010). The future for research on waterbirds in rice fields. Waterbirds 33:231-243.

Elphick, C. S., and L. W. Oring (2003). Conservation implications of flooding rice fields on winter waterbird communities. Agriculture Ecosystems and Environment 94:17-29.

Fasola, M., and X. Ruiz (1996). The value of rice fields as substitutes for natural wetlands for waterbirds in the Mediterranean region. Colonial Waterbirds 19:122-128.

Forés, E., and F. A. Comín (1992). Ricefields, a limnological perspective. Limnetica 8:105-109.

Hicklin, P. W., and A. L. Spaans (1992). The birds of the SML rice fields in Suriname: species composition, numbers and toxichemical threats. Canadian Wildlife Service, Ottawa, Canada, Technical Report Series 174.

Ibáñez, C., A. Curcó, X. Riera, I. Ripoll, and C. Sánchez (2010). Influence on birds of rice field management practices during the growing season: A review and an experiment. Waterbirds 33:167-180.

Instituto Riograndense do Arroz (IRGA) (2001). Arroz irrigado: Recomendações técnicas da pesquisa para o sul do Brasil. IRGA, Porto Alegre, Brazil.

Instituto Técnico de Pesquisa de Assessoria (ITEPA) (2011). Banco de dados Zona Sul. ITEPA-UCPel, Pelotas, Brazil.

Lanctot, R. B., D. E. Blanco, R. A. Dias, J. P. Isacch, A. A. Gill, J. B. Almeida, K. Delhey, P. F. Petracci, G. A. Bencke, and R. Balbueno (2002). Conservation status of the Buff-breasted Sandpiper: Historic and contemporary distribution and abundance in South America. Wilson Bulletin 114:44-72.

Lanctot, R. B., A. Hartman, L. W. Oring, and R. I. G. Morrison (2008). Response to Farmer (2008): Limitations of statistically derived population estimates, and suggestions for deriving national population estimates for shorebirds. The Auk 125: 983-985.

Leitão, S., P. Pinto, T. Pereira, and M. F. Brito (2007). Spatial and temporal variability of macroinvertebrate communities in two farmed Mediterranean rice fields. Aquatic Ecology 41: 373-386.

López-Lanús, B., and D. Blanco (2005). San Javier. In Áreas importantes para la conservación de las aves en Argentina. Sitios prioritarios para la conservación de la biodiversidad (A. S. Di Giacomo, Editor). Aves Argentinas/Asociación Ornitológica del Plata, Buenos Aires, Argentina. (Temas de Naturaleza y Conservación 5). pp. 440-441.

Lourenço, P. M., and T. Piersma (2009). Waterbird densities in South European rice fields as a function of rice management. Ibis 151:196-199.

Martínez-Vilalta, A. (1985). Descripción de la comunidad de limícolas invernante en el Delta del Ebro. Doñana Acta Vertebrata 12:211-229.

Mugica, L., M. Acosta, and D. Denis (2003). Variaciones espacio temporales y uso del hábitat por la comunidad de aves de la arrocera Sur del Jíbaro, Sancti Spiritus, Cuba. Biología 17:105113.

Norling, W., C. W. Jeske, T. F. Thigpen, and P. C. Chadwick (2012). Estimating shorebird populations during spring stopover in rice fields of the Louisiana and Texas gulf coastal plain. Waterbirds 35:361-370. 
Parsons, K. C., P. Mineau, and R. B. Renfrew (2010). Effects of pesticide use in rice fields on birds. Waterbirds 33:193-218.

Riera, X., A. Curcó, and C. Ibáñez (1997-1998). I'Efecte de tres mètodes de gestió agrícola sobre l'estructura de la comunitat d'ocells en arrossars del delta de l'Ebre. Butlletí Parc Natural Delta de l'Ebre 10:4-9.

Rolon, A. S., and L. Maltchik (2010). Does flooding of rice fields after cultivation contribute to wetland plant conservation in southern Brazil? Applied Vegetable Science 13:26-35.

Ruiz, A. (1998). Caracterización del área arrocera de la Región CREA Litoral Norte. Cuadernillo de Actualización Técnica 61: 10-13.

Scherr, S. J., and J. A. McNeely (2008). Biodiversity conservation and agricultural sustainability: Towards a new paradigm of 'ecoagriculture' landscapes. Philosophical Transactions of the Royal Society B 363:477-494.
Strum, K. M., M. J. Hooper, K. A. Johnson, R. B. Lanctot, M. E. Zaccagnini, and B. K. Sandercock (2010). Exposure of nonbreeding migratory shorebirds to cholinesterase inhibiting contaminants in the Western Hemisphere. The Condor 112:15-28.

Taylor, I. R., and M. C. Schultz (2010). Waterbird use of rice fields in Australia. Waterbirds 33:71-82.

Thomas, L., J. L. Laake, S. Strindberg, F. F. C. Marques, S. T. Buckland, D. L. Borchers, D. R. Anderson, K. P. Burnham, S. L. Hedley, J. H. Pollard, J. R. B. Bishop, and T. A. Marques (2006). Distance 5.0. Release Beta 3. Research Unit for Wildlife Population Assessment, University of St. Andrews, St. Andrews, UK.

Thompson, W. L. (2002). Towards reliable bird surveys: Accounting for individuals present but not detected. The Auk 119:18-25.

Western Hemisphere Shorebird Reserve Network (WHSRN) (2014). WHSRN sites. http://www.whsrn.org/whsrn-sites 